\title{
Sustainable Tourism in Southern Africa: \\ Local Communities and Natural Resources in Transition
}

(Edited) by Jarkko Saarinen, Fritz Becker, Haretsebe Manwa and Deon Wilson. Channel View Publications, St Nicholas House, 31-34 High Street, Bristol BS1 2AW, UK, 2009, 290 + xxiii (contents, cases and issues, figures, tables, plates, abbreviations, contributors, preface) \$US 49.95 (pbk) ISBN-13: 978-1-84541-108-4.

Ralf C Buckley

Griffith University, Australia

PUBLICATIONS IN REVIEW

PUBLICATIONS IN REVIEW

Ralf Buckley

International Centre for Ecotourism Research

Griffith University

Gold Coast campus, Qld, Australia, 4222

Tel: 07 5552-8675

Fax: 0755528895

E-mail: r.buckley@griffith.edu.au 
Finland might seem an unlikely partner for research on southern Africa, being rather different in climate, geography, society and culture. Like its Scandinavian neighbours, however, the Finnish Foreign Ministry funds a number of ongoing bilateral aid programs in African nations. The principal editor of this volume, well-known and energetic tourism geographer Jarkko Saarinen, clearly managed to appropriate a certain component of this program to establish collaborations with his colleagues in Botswana, Namibia and South Africa.

This book is the outcome, and one well worth reading. Of the 23 contributors, 19 are from these three countries, including the other three editors. There are five introductory chapters covering patterns, policies, gender and sustainability; five chapters focussing on tourism and conservation, and five examining various aspects of local community involvement. Southern Africa is taken to include Malawi, Zambia, Zimbabwe and Mozambique, as well as Namibia and Botswana and the independent nations of Swaziland and Lesotho inside South Africa itself.

By far the lion's share of international tourism to these nine nations is to South Africa, which garners $55.6 \%$ of arrivals and $83.7 \%$ of income (p. 31). Most of these arrivals, however, are from within the southern African region itself: they are cross-border business travel. The principal country of origin outside Africa is the UK, and there are fewer visitors from the UK than from five of the nine southern African nations. Other major originating countries are Germany and the USA, and each of these generates about the same number of visitors as Namibia (p. 33). The routes and fare structures of regional air carriers are critical constraints (p. 35).

Models for so-called pro-poor tourism are introduced early in the volume (p. 37), and the arguments for and against high and low volume and value tourism products, and private or community tourism operators, are re-examined in several chapters. As seems to be common in such debates, the concept of economic leakage seems to be misapplied, with incomplete appreciation of the structure of global trade in either travel or amenity consumables. Michael Hall notes correctly (p. 49) that tourism is affected far more by government policies relating to tax, land, migration, employment 
and investment than those specific to tourism; and also that policy is constructed by the powerful (p. 57), which is of course true, simply by definition.

Haretsebe Manwa describes gender-related difficulties with tourism and community-based natural resource management, CBNRM, in patriarchal communities. This has been recognised as a concern in development aid projects, but perhaps not yet in tourism. She also re-examines the much-cited CAMPFIRE program in Zimbabwe (pp. 190-192). Fritz Becker refers to tourism and CRNRM in Namibia, which does seem to have been quite successful, though not without internal contradictions (p. 97). Suzanne Scholz cautions (p. 165) that this is still a "work in progress”. David Mabunda and Deon Wilson report on the "Kruger experiment” of outsourcing in-park accommodation to the private sector. They point out (p. 131) that for a variety of commercial reasons, this is not a good approach for either tourists or the parks service. Maano Ramutsindela examines the history of transfrontier conservation areas, noting the critical role of Indigenous land rights claims, and Aderito Machava (pp. 179-183) adds a perspective on the creation of conservation refugees. This is indeed a very serious concern in a number of attempts worldwide to expand protected areas into lands held under traditional ownership.

In the book's third section, Naomi Moswete describes hunting tourism on communal lands in Botswana. She found that the majority San residents "felt marginalised by the Community Trust, which was seen as belonging to the wealthier ethnic Bangologa and Bakgalagadi residents”. Devolution of financial responsibility to a local community organisation had not assisted the poorest community members. Joseph Mbaiwa reports on tourism in the Okavango region of northern Botswana, in conjunction with Michael Darkoh, well-known for several decades of research on desertification. The result is a more balanced presentation than in some of Mbaiwa's other reports on this region. There is a chapter on the "commonage” program in Namaqualand, noting that tourism is as yet underutilised; a rather general chapter on opportunities for food tourism; and a concluding chapter which summarises the earlier contributions.

The strength of this book is in its involvement of local researchers in the southern African region itself. The international collaboration has provided a wider audience 
for their work, and I think this book will encourage other international researchers to seek them out for future collaborations. Jarkko Saarinen is to be commended for his initiative. The Aspects of Tourism series is very extensive and sometimes a little eclectic, but this is certainly one of its more interesting contributions. I expect to refer to it repeatedly. 